\title{
Declines in benthic macroinvertebrate populations in southern Lake Michigan, 1980-1993
}

\author{
Thomas F. Nalepa, David J. Hartson, David L. Fanslow, Gregory A. Lang, and \\ Stephen J. Lozano
}

\begin{abstract}
Densities of the major benthic macroinvertebrate groups declined dramatically at sites shallower than $50 \mathrm{~m}$ in southern Lake Michigan between 1980 and 1993. Declines in Diporeia, Oligochaeta, and Sphaeriidae ranged from 40 to $75 \%$ at these depths. Total densities declined from $16800 \cdot \mathrm{m}^{-2}$ in $1980-1981$ to $4800 \cdot \mathrm{m}^{-2}$ in $1992-1993$ at sites in the 16-30 m depth interval and from 21300 to $11300 \cdot \mathrm{m}^{-2}$ at sites in the $31-50 \mathrm{~m}$ depth interval. Changes at sites deeper than $50 \mathrm{~m}$ were minimal; only sphaeriids declined to any extent. Declines in oligochaetes and sphaeriids occurred uniformly throughout the nearshore region and over the entire sampling period. Declines in these two groups were most likely related to reductions in phosphorus loads and a general decrease in productivity in the nearshore area over the sampling period. On the other hand, declines in Diporeia occurred mainly in the later portion of the sampling period and were greatest in the southeastern region of the lake. Densities at many sites in the southeastern region were $<100 \cdot \mathrm{m}^{-2}$ in 1993 , down from $3000-8000 \cdot \mathrm{m}^{-2}$ in $1980-1987$. We hypothesize that the filtering activities of large populations of Dreissena polymorpha in nearshore waters may be having a negative impact on Diporeia in deeper waters by decreasing the amount of food available to this surface-feeding detritivore.
\end{abstract}

Résumé : La densité des principaux groupes de macroinvertébrés benthiques a fortement diminué entre 1980 et 1993 dans les zones peu profondes $(<50 \mathrm{~m})$ du sud du lac Michigan. Les déclins observés chez Diporeia, les oligochètes et les sphaeriides atteignaient 40 à $75 \%$ à ces profondeurs. Les densités totales sont passées de $16800 \cdot \mathrm{m}^{-2}$ en $1980-1981$ à $4800 \cdot \mathrm{m}^{-2}$ en 1992-1993 dans les zones de 16 à $30 \mathrm{~m}$ de profondeur et de 21300 à $11300 \cdot \mathrm{m}^{-2}$ dans les zones de 31 à $50 \mathrm{~m}$ de profondeur. Dans les secteurs plus profonds, les changements étaient de façon générale peu importants, les seuls déclins prononcés ayant été observés chez les sphaeriides. Les déclins chez les oligochètes et les sphaeriides se sont produits de façon uniforme à l'échelle de toute la zone côtière et durant toute la durée de l'échantillonnage. Les déclins chez ces deux groupes étaient vraisemblablement attribuables à des réductions des charges de phosphore et à une diminution générale de la productivité dans la zone côtière durant la période d'échantillonnage. Chez Diporeia, les déclins ont été observés principalement durant la dernière portion de la période d'échantillonnage et se sont révélés plus prononcés dans la région sud-est du lac. En plusieurs endroits de cette région, les densités sont passées de 3000 à $8000 \cdot \mathrm{m}^{-2}$ en $1980-1987$ à $<100 \cdot \mathrm{m}^{-2}$ en 1993 . Nous croyons que la filtration exercée par les fortes populations de Dreissena polymorpha dans les eaux côtières pourrait avoir nui aux populations de Diporeia établies en zones plus profondes en réduisant la quantité de nourriture disponible pour cette espèce détritivore se nourrissant en surface.

[Traduit par la Rédaction]

\section{Introduction}

Over the past few decades, nearshore regions of the Great Lakes have undergone dramatic changes in real and perceived trophic status as a result of two important events: the

Received February 5, 1998. Accepted July 17, 1998. J14409

T.F. Nalepa, ${ }^{1}$ D.L. Fanslow, and G.A. Lang. Great Lakes Environmental Research Laboratory, NOAA, 2205

Commonwealth Blvd., Ann Arbor, MI 48105. U.S.A.

D.J. Hartson. Cooperative Institute for Limnology and Ecosystems Research, University of Michigan, 2200 Bonisteel Blvd., Ann Arbor, MI 48109, U.S.A.

S.J. Lozano. U.S. Environmental Protection Agency, Mid-Continent Ecology Division, 6201 Congdon Blvd., Duluth, MN 55804, U.S.A.

${ }^{1}$ Author to whom all correspondence should be addressed. e-mail: nalepa@glerl.noaa.gov planned reduction of nutrient loads and the establishment of the zebra mussel (Dreissena polymorpha). Reductions in phosphorus inputs have led to declines in phytoplankton abundances and shifts in algal species composition in nearshore waters (Edsall and Charlton 1996) whereas the filtering activities of D. polymorpha have reduced phytoplankton, increased water clarity, and shifted productivity from the pelagic to the benthic region without any real change in trophic status (Fahnenstiel et al. 1995a, 1995b). Because benthic macroinvertebrate communities integrate changes in both the pelagic and benthic regions, trends in abundances and species composition are useful in assessing changes in overall system productivity as well as interpreting causes of observed changes.

Prior to the mid-1970s, excessive nutrient loads (phosphorus) in the Great Lakes led to increased pelagic productivity and deterioration of the benthic environment. Macroinvertebrate species that could best take advantage of increased 
Fig. 1. Location of the 40 sampling sites in southern Lake Michigan. Depth contours of 30, 50, and 90 m define the depth intervals by which the stations were grouped for data analysis. Each station represents a site that was originally sampled in the 1960s or earlier. Derivation of site designations is described in Nalepa (1987).

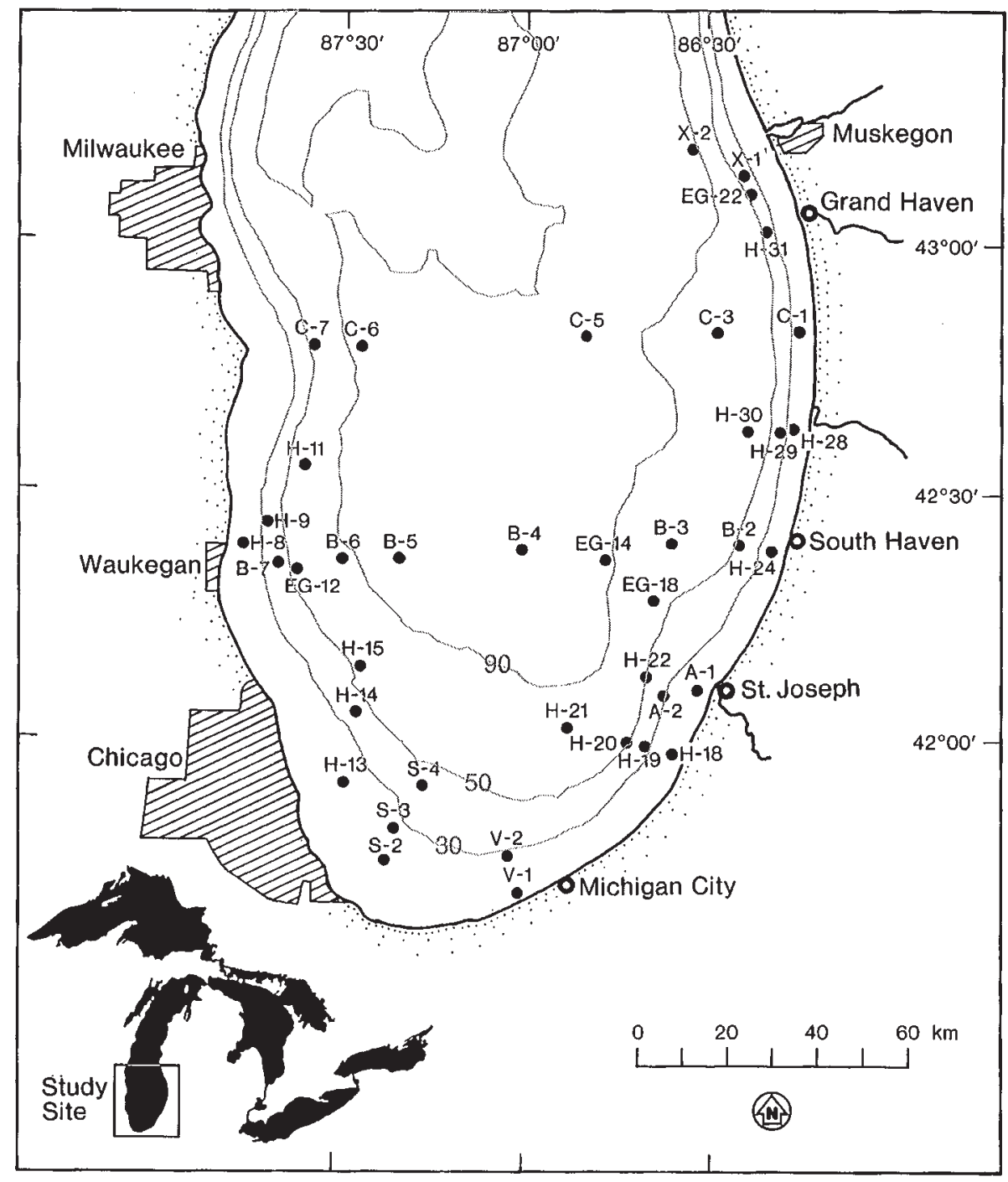

food inputs to the benthic region became abundant, while more sensitive forms declined (see Cook and Johnson 1974 for review). Since the reduction of phosphorus loads, there has been a general shift to communities indicative of improved conditions; changes in densities and species composition have generally been the reverse of changes when conditions were deteriorating (Johnson and McNeil 1986; Schloesser et al. 1995). For instance, in the Bay of Quinte, the density and biomass of some major benthic groups (oligochaetes, sphaeriids, and chironomids) declined between 1966 and 1984 in response to a decline in phosphorus loads and bay productivity (Johnson and McNeil 1986). Also, in western Lake Erie, declines in oligochaete abundances and shifts in species composition in nearshore waters between 1961 and 1982 indicated improved water quality (Schloesser et al. 1995).

The introduction and widespread abundance of $D$. polymorpha have confounded our interpretations of trophic trends using benthic macroinvertebrate communities. The overall impact of $D$. polymorpha's filtering activities on ben- thic populations has varied, depending on the feeding mode and life habit of the particular species or taxonomic group. Dreissena polymorpha has had a negative impact on some taxa via competitive exclusion (Nalepa et al. 1996; Dermott and Kerec 1997), a positive impact by increasing habitat complexity and detrital food (Stewart and Haynes 1994, Botts et al. 1996), or no impact at all (Dermott and Kerec 1997).

In this study, we assess long-term changes in benthic macroinvertebrate populations of the southern basin of Lake Michigan. Benthic communities in this basin are greatly influenced by changes in nutrient loads, since a large portion (43\%) of suspended material and total phosphorus enters the lake at the southern end (Robertson 1997). We collected samples in 1986-1987 and in 1992-1993 at the same sites that were sampled in 1980-1981 (Nalepa 1987). In the 1980-1981 survey, densities of the major benthic macroinvertebrate groups (Diporeia (Amphipoda), Oligochaeta, and Sphaeriidae) increased over twofold between the mid-1960s and 1980-1981 at depths <50 m (Nalepa 1987). This finding 
followed a similar trend of increasing densities between the early 1930s and 1964 (Robertson and Alley 1966). Both studies attributed increased densities to accelerated nutrient loads and higher productivity within the lake between the 1950s and early 1970s (Chapra 1977; Schelske 1978). A positive, direct relationship between pelagic productivity and densities of amphipods, oligochaetes, and sphaeriids is a common feature of large, deep lakes (Saether 1980). Reductions in phosphorus loads in the mid-1970s led to declines in total phosphorus, summer epilimnetic chlorophyll, and the intensity of the spring diatom bloom by the late 1970s early 1980s (Vandercastle 1985; Scavia et al. 1986; Chang and Rossman 1988). Nalepa (1987) hypothesized that macroinvertebrate densities in southern Lake Michigan in 1980-1981 had not yet reflected observed productivity declines in the pelagic region. Since phosphorus loads have continued to decline through the 1980s (Johengen et al. 1994), our subsequent surveys were designed to determine if the macroinvertebrate community had now responded to these productivity changes. Furthermore, with $D$. polymorpha becoming established in southern Lake Michigan in 1989 (Marsden et al. 1993), our surveys provide a relative measure of initial changes in the macroinvertebrate community that may have resulted from $D$. polymorpha filtering activities.

\section{Materials and methods}

Samples were collected in 1986-1987 and 1992-1993 at the same 40 sites sampled in 1980-1981 using exactly the same methods (Nalepa 1987) (Fig. 1). Bottom substrates ranged from coarse sand and gravel to fine silt, and sampling depths ranged from 16 to $157 \mathrm{~m}$. Exact location, water depth, and substrate type at each site are given in Nalepa et al. (1985). Sampling was conducted in spring (mid-May - early June), summer (late July - early August), and fall (September-October) over a 1-week period in each season of each year. The sampling period sometimes extended longer than 1 week because of poor weather conditions. Samples were taken in triplicate with a Ponar grab $\left(\right.$ area $\left.=0.046 \mathrm{~m}^{2}\right)$ and washed into an elutriation device fitted with a nitex sleeve having $0.5-\mathrm{mm}$ openings (Nalepa et al. 1985). Retained material was immediately preserved in $10 \%$ buffered formalin containing rose bengal stain.

Retained residue was placed into a white enamel pan and organisms were picked, counted, and sorted into major benthic groups (Diporeia, Oligochaeta, Sphaeriidae, Chironomidae, Gastropoda, D. polymorpha, and others). In some samples, the number of organisms was extremely large and only a randomly chosen portion (one eighth to one half) of the residue was picked and then applied to the entire sample. All organisms collected in 1980-1981 and 1992-1993 were identified to the lowest practical taxonomic level, but organisms collected in 1986-1987 were identified only to the group level as given above. For oligochaetes, between 75 and 100 individuals in a replicate (proportionately split with a Folsom plankton splitter when numbers were higher) were cleared in lactophenol before identification. Only oligochaetes with a prostomium were included in abundance estimates. Since fragments (without prostomium) can only be recognized during the process of species identification and not when counted and sorted, the total number of oligochaetes in 1986-1987 at each site was corrected based on the mean proportion of fragments found in the other four years at the same site.

\section{Results}

Spatial and temporal trends were examined by dividing the sampling sites into four depth intervals (16-30, 31-50, $51-90$, and $>90 \mathrm{~m}$ ) and calculating yearly means for the three major macroinvertebrate groups, Diporeia, Oligochaeta, and Sphaeriidae. These depth intervals are consistent with prior characterization of depth-macroinvertebrate associations in Lake Michigan (Alley and Mozley 1975; Nalepa 1987) and approximate regions of varying sediment resuspension and deposition within the southern basin (Chambers and Eadie 1981; Eadie et al. 1984). Between 1980 and 1993 , there was a general downward trend in density in each of the three macroinvertebrate groups at the 16-30 and 31-50 m intervals (Table 1). At these two shallowest intervals, Diporeia declined 68 and $43 \%$, respectively, oligochaetes declined 75 and $40 \%$, and sphaeriids declined 75 and $72 \%$. Overall, total mean density at the 11 sites in the $16-30 \mathrm{~m}$ interval declined from $16800 \cdot \mathrm{m}^{-2}$ in 1980 to $4800 \cdot \mathrm{m}^{-2}$ in 1993, while total mean density at the 12 sites in the $31-50 \mathrm{~m}$ interval declined from 21300 to $11300 \cdot \mathrm{m}^{-2}$. Yearly differences at these two shallow intervals were significant for each group (ANOVA, $P<0.01$ ) except for sphaeriids at $16-$ $30 \mathrm{~m}(P=0.16)$ (Table 1$)$. When yearly differences were significant, multiple range tests (Tukey HSD) indicated that densities in 1993 were significantly lower $(P<0.05)$ than densities in most other years except for densities in 1992 (Table 1).

Density trends at the two deeper intervals were not as consistent as at the shallower intervals. Overall, a downward trend in total density was not readily apparent (Table 1). Yearly differences were significant for Diporeia at these two deeper depth intervals $(P<0.001)$, but mean densities of Diporeia in 1992 or 1993 were not always lower than means in previous years (see low densities in 1981 at both intervals; Table 1). For oligochaetes, densities at the 51-90 m interval were lowest in 1993, but were only significantly lower than densities in 1980 (Tukey HSD, $P<0.05$ ). Yearly differences in density at the $>90 \mathrm{~m}$ interval were not significant $(P=0.80)$. Yearly differences in sphaereiid densities were significant at both intervals $(P<0.05)$, with lowest densities occurring in 1993.

Since the 1986-1987 survey was conducted just prior to the establishment of $D$. polymorpha in Lake Michigan, these survey years are important when comparing potential impacts of phosphorus reductions versus $D$. polymorpha filtering activities. Declines between 1980-1981 and 1986-1987 represent potential responses to phosphorus load reductions, while declines between 1986-1987 and 1992-1993 represent potential responses to both phosphorus reductions and D. polymorpha. In order to distinguish the relative impact of these two events, we calculated and then compared rates of decline (percent decline per year) for the two time periods (1980-1981 to 1986-1987, 1986-1987 to 1992-1993) for each of the three groups (Table 2). At the 16-30 m interval, rates of decline were greater in the 1980-1981 to 1986-1987 time period for oligochaetes and sphaeriids, but greater in the 1986-1987 to 1992-1993 time period for Diporeia. Decline rates in oligochaetes were significant for both time periods (paired $t$-test, $P<0.05$ ) (Table 2), declines in Diporeia were significant only in the later period, and declines in sphaeriids were not significant $(P>0.05)$ for either period. This suggests that, of the three groups, oligochaetes were most responsive to nutrient reductions and that Diporeia 
Table 1. Mean $( \pm \mathrm{SE})$ yearly densities $\left(\right.$ no. $\left.\cdot \mathrm{m}^{-2}\right)$ of the three major macroinvertebrate groups at various depth intervals in southern Lake Michigan.

\begin{tabular}{|c|c|c|c|c|c|c|c|}
\hline & 1980 & 1981 & 1986 & 1987 & 1992 & 1993 & ANOVA \\
\hline \multicolumn{8}{|l|}{ Depth: $16-30 \mathrm{~m}$} \\
\hline Diporeia & $8310 \pm 1242 a$ & $7455 \pm 987 a$ & $8041 \pm 1292 a$ & $5377 \pm 826 a$ & $2618 \pm 504 b$ & $2698 \pm 543 b$ & $<0.001$ \\
\hline Oligochaeta & $6393 \pm 2286 a$ & $5613 \pm 1578 a$ & $3127 \pm 933 a b$ & $2925 \pm 960 a b$ & $1713 \pm 376 a b$ & $1647 \pm 434 b$ & 0.002 \\
\hline Sphaeriidae & $2129 \pm 577$ & $2643 \pm 741$ & $1257 \pm 345$ & $1348 \pm 347$ & $1381 \pm 384$ & $535 \pm 123$ & 0.156 \\
\hline Total & 16832 & 15711 & 12425 & 9650 & 5712 & 4880 & \\
\hline \multicolumn{8}{|l|}{ Depth: $31-50 \mathrm{~m}$} \\
\hline Sphaeriidae & $3789 \pm 396 a$ & $2862 \pm 381 a$ & $2394 \pm 255 a$ & $3083 \pm 418 a$ & $2273 \pm 303 a$ & $1068 \pm 166 b$ & $<0.001$ \\
\hline Total & 21313 & 17247 & 17493 & 18611 & 15470 & 11255 & \\
\hline \multicolumn{8}{|c|}{ Depth: $51-90 \mathrm{~m}$} \\
\hline Diporeia & $6466 \pm 285 a c$ & $5071 \pm 375 b$ & $6622 \pm 456 a c$ & $7652 \pm 346 a c$ & $6380 \pm 332 a c$ & $5352 \pm 373 a b$ & $<0.001$ \\
\hline Oligochaeta & $2190 \pm 184 a$ & $2077 \pm 154 a b$ & $2248 \pm 204 a b$ & $1976 \pm 232 a b$ & $2042 \pm 135 a b$ & $1530 \pm 97 b$ & 0.026 \\
\hline Sphaeriidae & $758 \pm 93 a$ & $844 \pm 98 a$ & $838 \pm 122 a$ & $797 \pm 111 a$ & $801 \pm 153 a$ & $384 \pm 72 b$ & $<0.001$ \\
\hline Oligochaeta & $989 \pm 167$ & $1007 \pm 227$ & $1132 \pm 271$ & $1384 \pm 426$ & $1179 \pm 151$ & $1123 \pm 159$ & 0.794 \\
\hline Sphaeriidae & $198 \pm 37 a$ & $191 \pm 53 a b$ & $329 \pm 184 a b$ & $151 \pm 46 a b$ & $113 \pm 30 a b$ & $98 \pm 36 b$ & 0.028 \\
\hline Total & 4849 & 3605 & 6775 & 6207 & 4487 & 4447 & \\
\hline
\end{tabular}

Note: Differences between years were tested using ANOVA on $\log (x+1)$-transformed values. Statistical tests and estimates of variability were based on means of three replicates per site per sampling date. Values followed by a different letter are significantly different (Tukey HSD, $P<0.05$ ).

Table 2. Rates of decline for the three major macroinvertebrate groups for each survey period.

\begin{tabular}{lccc}
\hline & Diporeia & Oligochaeta & Sphaeriidae \\
\hline Depth: $16-30$ m & & & \\
1980-1981 to $1986-1987$ & $2.6(6,0.345)$ & $7.2(9,0.014)$ & $7.5(7,0.216)$ \\
1986-1987 to $1992-1993$ & $10.0(8,0.005)$ & $6.0(11,0.001)$ & $4.5(8,0.069)$ \\
1980-1981 to $1992-1993$ & $5.5(11,<0.001)$ & & \\
Depth: $30-50$ m & & $0.5(7,0.403)$ & \\
1980-1981 to $1986-1987$ & $0.7(6,0.758)$ & $3.5(10,0.002)$ & $2.9(7,0.549)$ \\
$1986-1987$ to $1992-1993$ & $2.1(8,0.014)$ & $2.0(11,0.003)$ & $6.5(8,0.031)$ \\
$1980-1981$ to $1992-1993$ & $2.3(8,0.085)$ & $4.1(12,0.001)$ \\
\hline
\end{tabular}

Note: Declines were calculated as the percent decline per year (assume 6 years between surveys). The first value in parentheses is the number of sites showing a decrease in densities over the given time period. The second value in parentheses is the $P$ for a paired $t$-test comparing densities of all sites in that depth interval. For the 16-30 m interval, one site was not collected in 1986-1987; thus, $n=10$ for the first two time periods and $n=11$ for the last. Similarly, one site was not sampled in the $31-50 \mathrm{~m}$ interval in $1986-1987$; thus, $n=11$ for the first two time periods and $n=12$ for the last.

may have been most affected by $D$. polymorpha. For the 31$50 \mathrm{~m}$ interval, rates of decline in all three groups were greater in the 1986-1987 to 1992-1993 time period. Declines were significant $(P<0.05)$ (Table 2$)$ for each group during this later period, but were not significant for the earlier period $(P>0.05)$.

The effects of sampling season (spring, summer, fall) were not significant for any of the groups (ANOVA, $\log (x+1)$ transformed, $P>0.05)$ except for Diporeia at the $16-30 \mathrm{~m}$ interval $(P=0.02)$. Diporeia abundances were highest in the spring and declined through summer and fall. This species has a 1-year life cycle at these depths, and population densities are high in the spring when newly hatched young enter the population but then decline (Winnell and White 1984).

Declines in densities were observed at most all sites $<50$ m between 1980-1981 and 1992-1993 (Table 2). To determine if declines occurred to a similar extent over all sites at these depths, all sites $<50 \mathrm{~m}$ (23 total) were ranked by relative mean density in both 1980-1981 and 1992-1993 and rank differences between the two 2-year surveys compared. For oligochaetes and sphaeriids, rank differences were not significant (chi-square, $P>0.05$ ), indicating that relative declines in these two groups were consistent for all sites at these depths. However, for Diporeia, there was a significant difference in ranks $(P<0.01)$, indicating that densities at some sites declined more than at others. Clearly, Diporeia declined to a greater extent at sites $<50 \mathrm{~m}$ in the southeastern portion of the lake (Fig. 2). All 11 sites where Diporeia declined more than 60\% between 1980-1981 and 19921993 were located in this area of the lake (Fig. 3). The mean decline at these sites was $81.6 \%$ (range 60.3-99.2\%), while the mean decline at the other sites where Diporeia decreased was only $26.2 \%$ (range $7.0-49.0 \%$ ). At four of the sites (A-1, H-18, S-2, V-1), densities in 1993 were $<100 \cdot \mathrm{m}^{-2}$. Mean densities at these same sites in 1980-1987 ranged from 3381 to $8294 \cdot \mathrm{m}^{-2}$.

The trophic status of the most common oligochaete species is generally well known; thus, community composition 
Fig. 2. Densities (no. $\mathrm{m}^{-2} \times 10^{3}$ ) of Diporeia, Oligochaeta, and Sphaeriidae in each of the survey years. (Figure 2 is continued on next page.)

\section{Diporeia}
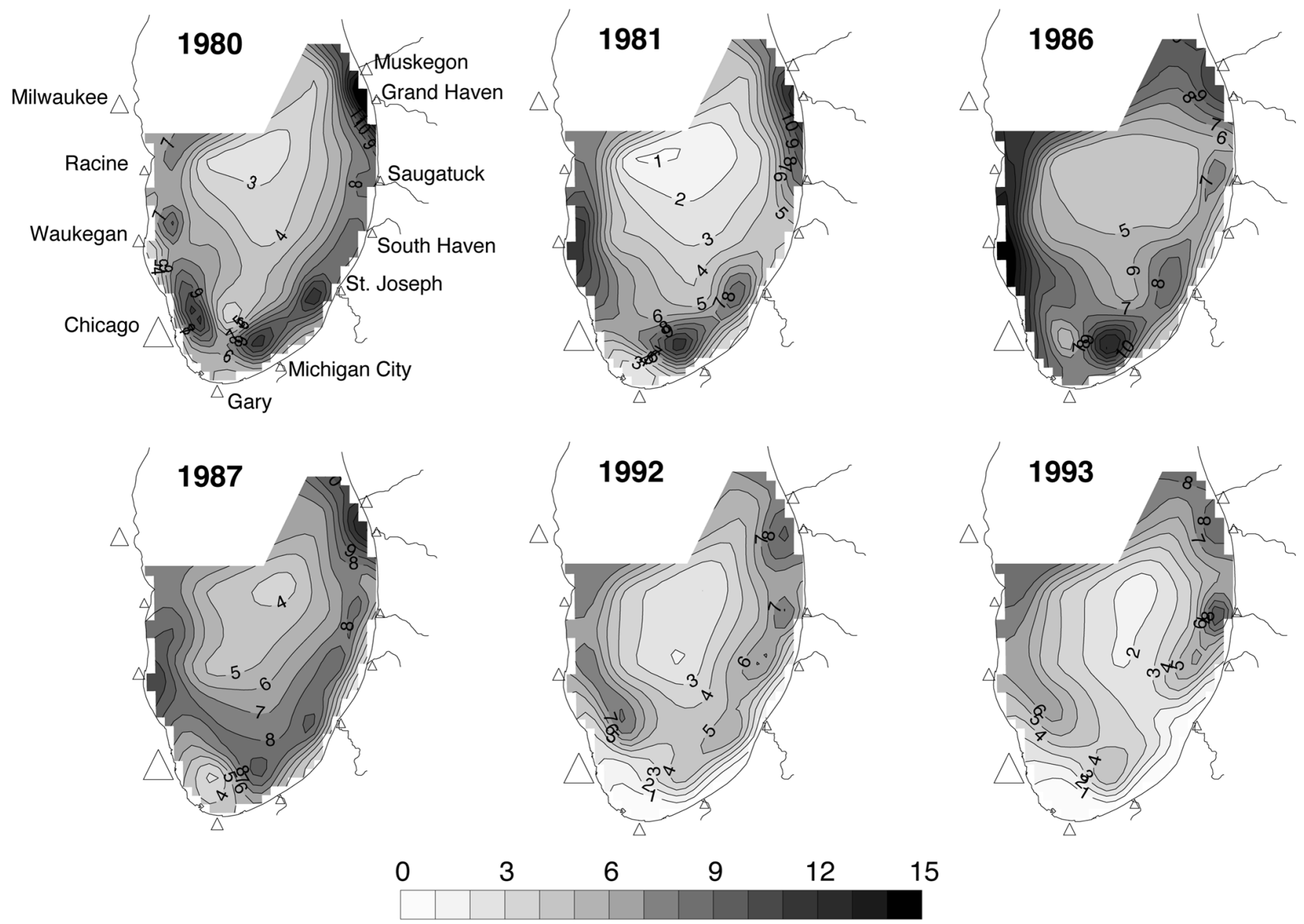

has often been used to assess a lake's trophic state (Milbrink 1983; Lauritsen et al. 1985) and also to assess changes in trophic state over time (Lang and Reymond 1992; Schloesser et al. 1995). Species can be divided into three categories based on their distribution and abundance relative to known areas of enrichment: type 1, largely restricted to oligotrophic waters; type 2, characteristic of mesotrophic conditions; type 3 , tolerant of extreme organic enrichment. The abundance of each of the major species and the percentage of individuals in each trophic category in 1980-1981 and 1992-1993 were compared (Table 3). Dominant species in each category, regardless of time period, were Stylodrilus heringianus in type 1 (98\%), Potamothrix vejdovskyi in type 2 (73\%), and Limnodrilus hoffmeisteri in type $3(72 \%)$. The proportion of individuals in each trophic category (relative to the total number collected) changed significantly (chi-square, $P<$ 0.05) between 1980-1981 and 1992-1993 at each depth interval (Table 3). In effect, differences between the two survey periods were a result of changes in the proportion of type 1 individuals, essentially all $S$. heringianus, and of changes in the proportion of individuals categorized as unidentifiable immatures. The proportion of $S$. heringianus in- creased between 1980-1981 and 1992-1993 at the 16-30, 51-90, and $>90 \mathrm{~m}$ intervals, while the proportion of unidentifiable immatures declined. Because $S$. heringianus can be identified to species even when immature, most of the unidentifiable individuals were likely species of types 2 and 3 . These changes would indicate less eutrophic conditions in 1992-1993 than in 1980-1981 at these depths. However, changes in species composition at the 31-50 m interval were inconsistent with those at the other three depth intervals. The proportion of $S$. heringianus declined, while the proportion and actual abundance of unidentifiable immatures increased (Table 3).

Other commonly collected macroinvertebrate taxa included Chironomidae, Gastropoda, and D. polymorpha. Densities of the former two taxa were low, and they comprised only a minor portion of the total macroinvertebrate community. Mean yearly densities between 1980 and 1993 were highest at the 16-30 $\mathrm{m}$ interval for both taxa and ranged from 173 to $320 \cdot \mathrm{m}^{-2}$ for chironomids and from 13 to $88 \cdot \mathrm{m}^{-2}$ for gastropods. Of special interest are the abundance and distribution of $D$. polymorpha, since the filtering activities of this species can affect food inputs to macroinvertebrate 
Fig. 2 (continued).

\section{Oligochaeta}
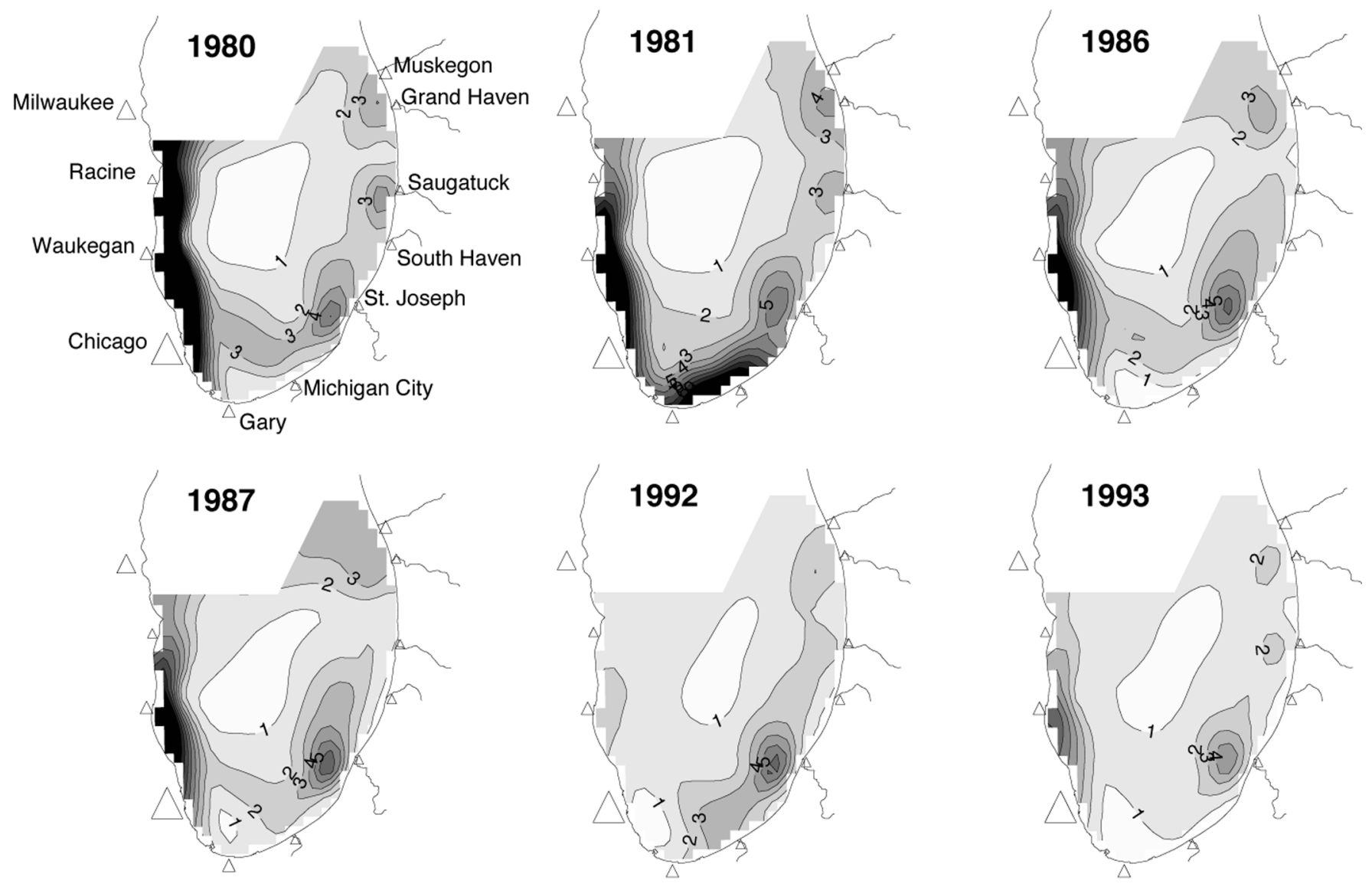

populations. Dreissena polymorpha was first reported from Lake Michigan in 1989 in the nearshore region near Chicago and by 1993 had colonized all hard substrates within about $7 \mathrm{~km}$ from shore from Waukegan to Michigan City (Marsden et al. 1993). In 1993, mean densities ranged from 50000 to about $100000 \cdot \mathrm{m}^{-2}$ on the extensive reefs and shoals in this region (Marsden et al. 1993). None of our sites were located in this area (Ponar grab cannot sample in hard substrate areas), so densities of $D$. polymorpha in our surveys were not representative of overall densities within the southern basin. Nevertheless, our surveys in 1992 and 1993 do provide a measure of relative distributions and abundances. Dreissena polymorpha was found at all sites in the 16-30 m interval in both 1992 and 1993, with densities generally higher in the later year (Fig. 4). Densities in 1993 were $<500 \cdot \mathrm{m}^{-2}$ except at station $\mathrm{V}-1$, where mean densities were $2889 \cdot \mathrm{m}^{-2}$ in 1992 and $18906 \cdot \mathrm{m}^{-2}$ in 1993 . Of the 12 sites in the 31-50 $\mathrm{m}$ interval, D. polymorpha was collected at five sites in 1992 and at 10 sites in 1993 (maximum mean density $133 \cdot \mathrm{m}^{-2}$ ), and of the 11 sites in the 51-90 m interval, D. polymorpha was collected at one site in 1992 and at three sites in 1993 (maximum mean density $9 \cdot \mathrm{m}^{-2}$ ). Dreissena polymorpha was not found at sites deeper than $90 \mathrm{~m}$.

\section{Discussion}

Declines in densities of the three dominant macroinvertebrate groups, Diporeia, oligochaetes, and sphaeriids, at depths $<50 \mathrm{~m}$ in southern Lake Michigan between 1980 and 1993 basically reverse a trend of increasing densities that occurred between 1930 and 1964 (Robertson and Alley 1966) and between the mid-1960s and 1980-1981 (Nalepa 1987). These declines correlate well with decreasing trends in phosphorus loads and pelagic productivity over the same time period. After phosphorus control measures were initiated in the mid-1970s, loads declined in the 1980s and remained lower through 1993 (Johengen et al. 1994; IJC, Windsor, Ont., unpublished data), and phosphorus concentrations decreased between the late 1970s and the early 1980s (Scavia et al. 1986; Chang and Rossman 1988), as did the intensity of the spring diatom bloom (Vandercastle 1985). Dated cores from the area of highest sedimentation in the southern basin show a similar trend: phosphorus concentrations in the sediment declined through the 1980s after a peak in the late 1960s - early 1970s (T. Johengen, Cooperative Institute for Limnology and Ecosystems Research, unpublished data). Also, primary productivity declined be- 
Fig. 2 (concluded).

\section{Sphaeriidae}
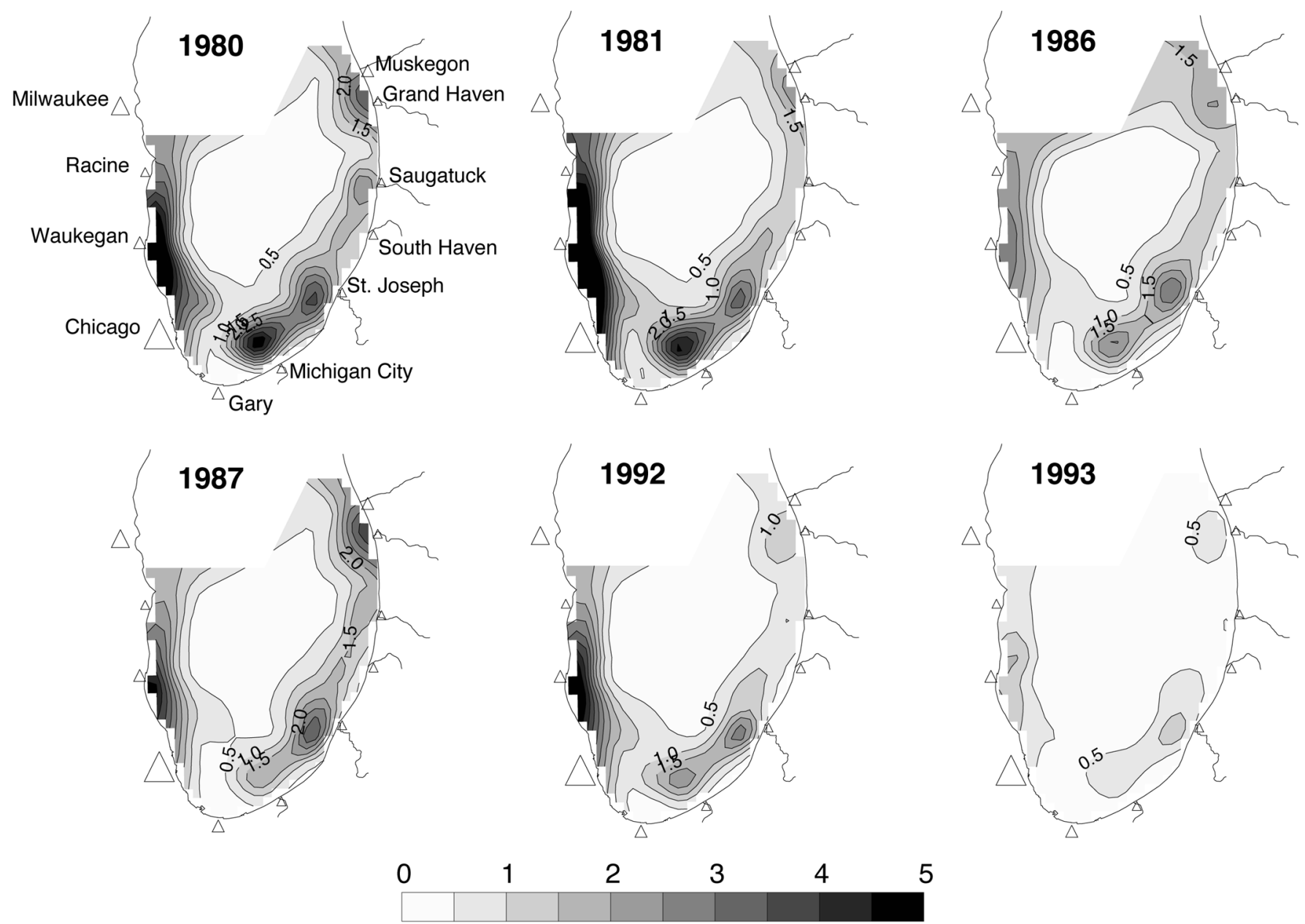

tween the early 1980s and early 1990s (G.L. Fahnenstiel, Great Lakes Environmental Research Laboratory, personal communication); however, recent declines may be more related to the filtering activities of $D$. polymorpha than to phosphorus load reductions. With corresponding declines in macroinvertebrate densities through the 1980s and early 1990s, densities in 1993 were equal to or lower than densities found in the mid-1960s (Table 4).

In the period between 1980-1981 and 1986-1987, when productivity in Lake Michigan was declining and $D$. polymorpha was not yet present, the two groups that declined to the greatest extent in the nearshore region were oligochaetes and sphaeriids, while declines in Diporeia were minimal. The two former groups generally respond directly to changes in benthic food inputs (Wiederholm 1980; Clarke et al. 1997), but for Diporeia, other factors such as fish predation may complicate interpretations of relationships between benthic food inputs and abundances (Johnson and McNeil 1986; McDonald et al. 1990). When densities of all three groups increased two- to fivefold at depths $<50 \mathrm{~m}$ between the mid-1960s and 1980-1981, Nalepa (1987) attributed the increases to enrichment and greater benthic food inputs but, in the case of Diporeia, provided evidence that suggested
Fig. 3. Region of the study area where Diporeia declined more than $60 \%$ between 1980-1981 and 1992-1993.

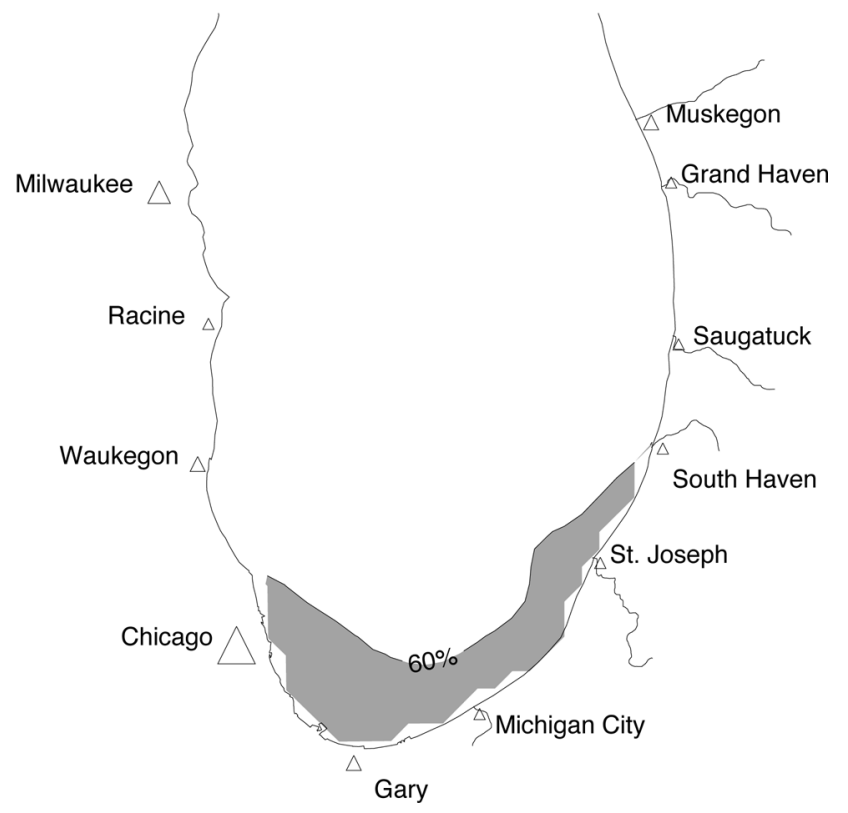


Table 3. Mean densities $\left(\right.$ no. $\cdot \mathrm{m}^{-2}$ ) of oligochaete species in 1980-1981 and 1992-1993 in each of four depth intervals.

\begin{tabular}{|c|c|c|c|c|c|c|c|c|}
\hline & \multicolumn{2}{|l|}{$16-30 \mathrm{~m}$} & \multicolumn{2}{|l|}{$30-50 \mathrm{~m}$} & \multicolumn{2}{|l|}{$50-90 \mathrm{~m}$} & \multicolumn{2}{|l|}{$90-156 \mathrm{~m}$} \\
\hline & 1980-1981 & 1992-1993 & 1980-1981 & 1992-1993 & 1980-1981 & 1992-1993 & 1980-1981 & 1992-1993 \\
\hline \multicolumn{9}{|l|}{ Taxa } \\
\hline \multicolumn{9}{|l|}{ Lumbriculidae } \\
\hline $\begin{array}{l}\text { Stylodrilus } \\
\quad \text { heringianus (1) }\end{array}$ & 1473 & 608 & 2974 & 1262 & 1216 & 1247 & 681 & 1010 \\
\hline A. limnobius (2) & 2 & 0 & 0 & 0 & 0 & 0 & 0 & 0 \\
\hline A. pluriseta (2) & 175 & 7 & 7 & $<1$ & 0 & 0 & 0 & 0 \\
\hline Ilyocryptus freyi (2) & 0 & 3 & 0 & 0 & 0 & 0 & 0 & 0 \\
\hline I. templetoni $(2)$ & 0 & 1 & 0 & 1 & $<1$ & 0 & 0 & 0 \\
\hline L. spiralis (3) & 7 & 0 & 2 & 0 & $<1$ & 0 & $<1$ & 0 \\
\hline L. profundicola (1) & 5 & 8 & 11 & 14 & 3 & 4 & 1 & $<1$ \\
\hline L. udekemianus (3) & $<1$ & $<1$ & 0 & $<1$ & 0 & 0 & 0 & 0 \\
\hline Opisthonais serpentia & 0 & $<1$ & 0 & 0 & 0 & 0 & 0 & 0 \\
\hline $\begin{array}{l}\text { Potamothrix } \\
\quad \text { moldaviensis (2) }\end{array}$ & 21 & 8 & 46 & 68 & 1 & $<1$ & 0 & 0 \\
\hline P. vejdovskyi (2) & 295 & 58 & 439 & 387 & 17 & 35 & 0 & $<1$ \\
\hline $\begin{array}{l}\text { Quistrodrilus } \\
\quad \text { multisetosus (3) }\end{array}$ & 117 & 1 & $<1$ & 2 & $<1$ & 0 & 0 & 0 \\
\hline $\begin{array}{l}\text { Rhyacodrilus } \\
\text { coccineus }(1)\end{array}$ & $<1$ & $<1$ & $<1$ & 4 & 0 & 0 & 0 & 0 \\
\hline $\begin{array}{l}\text { Immatures without } \\
\text { hair setae }\end{array}$ & 3253 & 683 & 936 & 1005 & 426 & 256 & 28 & 24 \\
\hline $\begin{array}{l}\text { Immatures with } \\
\text { hair setae }\end{array}$ & 211 & 49 & 211 & 788 & 142 & 94 & 84 & 42 \\
\hline Naididae $(11 \text { species })^{a}$ & 69 & 31 & 2 & 0 & 1 & $<1$ & $<1$ & 0 \\
\hline Type 1 & $1486(24.8)$ & $620(36.7)$ & $3067(61.4)$ & $1348(35.2)$ & $1222(57.3)$ & $1254(70.3)$ & $683(68.4)$ & $1010(87.7)$ \\
\hline Type 2 & $511(8.5)$ & $176(10.4)$ & $492(9.8)$ & 456 (11.9) & $18(0.8)$ & $35(2.0)$ & $0(0.0)$ & $<1(<0.1)$ \\
\hline Type 3 & 439 (7.3) & $125(7.4)$ & $220(4.4)$ & $212(5.5)$ & 168 (7.9) & $76(4.3)$ & $22(2.2)$ & $21(1.8)$ \\
\hline Other & $3567(59.4)$ & $767(45.4)$ & $1216(24.3)$ & $1812(47.3)$ & $727(34.1)$ & 419 (23.5) & $293(29.4)$ & $121(10.5)$ \\
\hline Total & 6003 & 1688 & 4995 & 3828 & 2135 & 1784 & 998 & 1152 \\
\hline
\end{tabular}

Note: The type category of each species is given in parentheses next to the species name (see text for explanation of categories). Also given is the percentage of individuals (in parentheses) in each of three trophic categories.

${ }^{a}$ Arcteonais lomondi, Chaetogaster diaphanus, Nais alpina, Nais elinguis, Nais simplex, Nais variabilis, Piguetiella michiganensis, Stylaria fossularius, Stylaria lacustris, Uncinata uncinais, Vejdovskyella intermedia.

decreased fish predation was also a factor. In the Bay of Quinte, oligochaetes and sphaeriids declined in response to phosphorus reductions, but a noted increase in Diporeia was attributed to the collapse of the white perch (Morone americana) population (Johnson and McNeil 1986). In adjacent Lake Ontario, where white perch populations were never abundant, declines in standing stocks of Diporeia were similar to those for oligochaetes and sphaeriids.

In our study, each of the three groups continued to decline between 1986-1987 and 1992-1993. While decline rates in oligochaetes and sphaeriids over this period were generally comparable with decline rates in 1980-1981 to 1986-1987, 
Fig. 4. Distribution and density $\left(\right.$ no. $\left.\cdot \mathrm{m}^{-2}\right)$ of the zebra mussel Dreissena polymorpha in 1992 and 1993 . Note log scale.
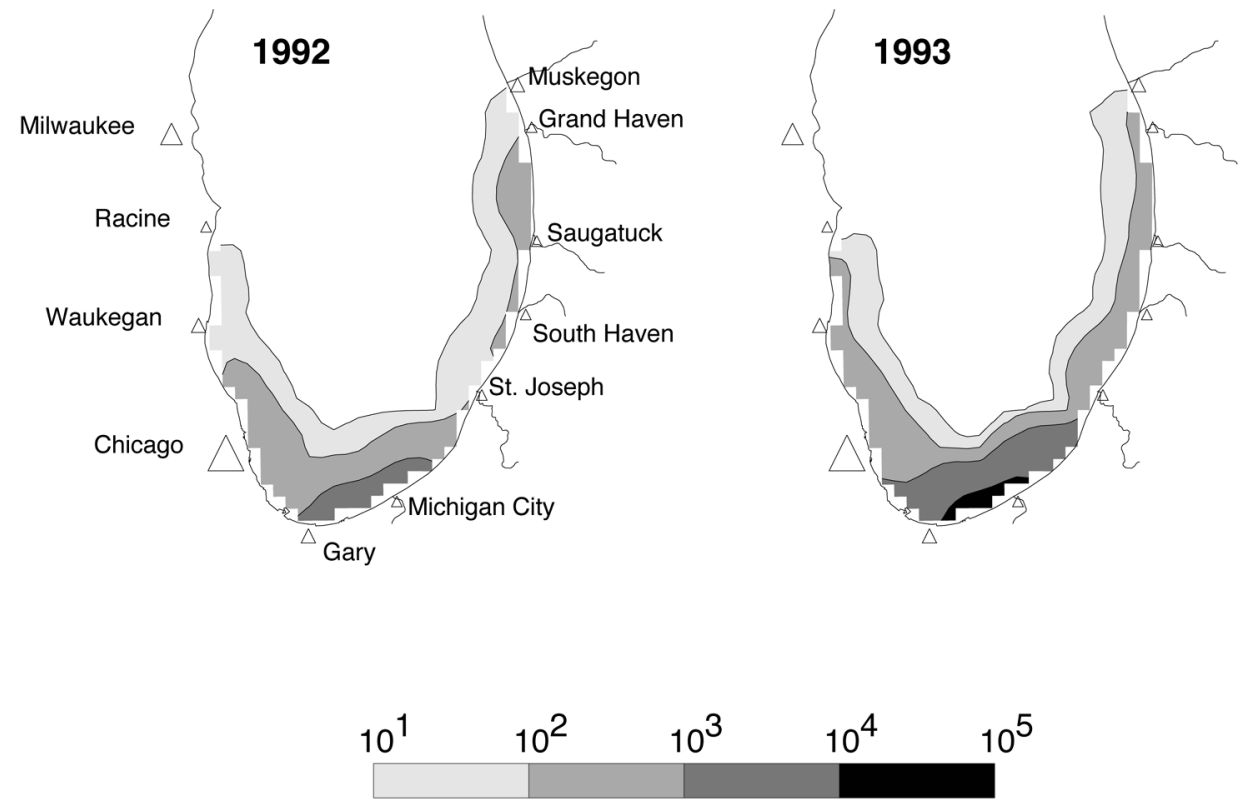

Table 4. Mean $( \pm \mathrm{SE})$ density $\left(\right.$ no. $\left.\cdot \mathrm{m}^{-2}\right)$ of the three major macroinvertebrate groups at different depth intervals in 19621967 and 1993.

\begin{tabular}{lccl}
\hline & $1962-1967$ & 1993 & $P$ \\
\hline Depth: 16-30 m & & & \\
$\quad$ Diporeia & $3061 \pm 962$ & $2158 \pm 847$ & $\mathrm{~ns}$ \\
Oligochaeta & $2090 \pm 983$ & $1599 \pm 827$ & $\mathrm{~ns}$ \\
Sphaeriidae & $1860 \pm 1251$ & $508 \pm 213$ & $\mathrm{~ns}$ \\
$\quad$ Total & 7011 & 4265 & \\
Depth: $31-50 \mathrm{~m}$ & & & \\
Diporeia & $6361 \pm 921$ & $5648 \pm 1155$ & $\mathrm{~ns}$ \\
Oligochaeta & $4096 \pm 903$ & $2733 \pm 715$ & $\mathrm{~ns}$ \\
Sphaeriidae & $2859 \pm 579$ & $1273 \pm 399$ & $<0.05$ \\
Total & 13316 & 9654 & \\
Depth: $51-90 \mathrm{~m}$ & & & \\
Diporeia & $3974 \pm 374$ & $5161 \pm 705$ & $\mathrm{~ns}$ \\
Oligochaeta & $1690 \pm 591$ & $1494 \pm 168$ & $\mathrm{~ns}$ \\
Sphaeriidae & $729 \pm 150$ & $362 \pm 134$ & $<0.05$ \\
Total & 6393 & 7017 & \\
Depth: $>90 \mathrm{~m}$ & & & \\
Diporeia & $2796 \pm 543$ & $3372 \pm 940$ & $\mathrm{~ns}$ \\
Oligochaeta & $2089 \pm 840$ & $1040 \pm 237$ & $\mathrm{~ns}$ \\
Sphaeriidae & $178 \pm 48$ & $106 \pm 68$ & $<0.05$ \\
Total & 5063 & 4518 & \\
\hline
\end{tabular}

Note: The 1962-1967 data were taken from Alley and Mozley (1975) and A.M. Beeton (Great Lakes Environmental Research Laboratory, unpublished data). Because sites were sampled at different frequencies in 1962-1967, SEs were derived from station means. $n=10(<30 \mathrm{~m}), n=8$ (31-50 m), $n=8(51-90 \mathrm{~m})$, and $n=5(>90 \mathrm{~m})$. Only stations sampled in both periods were included. Differences between periods were tested using the Wilcoxon matched-pairs signed-rank test. ns, not significant.

decline rates in Diporeia increased fivefold and were focused primarily in the south-southeastern portion of the lake. Since $D$. polymorpha became established in this area in 1989, we hypothesize that food competition with $D$. polymorpha may have led to accelerated declines in Diporeia. By 1993, D. polymorpha had heavily infested the south- southwestern portion of the lake, as extensive shoals and reefs in this area provided an ideal substrate for colonization (Marsden et al. 1993). Water clarity at many sites in this region increased twofold between 1990 and 1993 (Marsden et al. 1993), an increase similar to that found in other Great Lakes areas heavily infested by D. polymorpha (Fahnenstiel et al. 1995a). Diporeia relies on freshly sedimented organic matter as a food source (i.e., mostly diatoms), while $D$. polymorpha is a filter-feeder that intercepts this material before it actually settles to the bottom. In the profundal region of eastern Lake Erie, Diporeia declined 88\% after Dreissena became established; also, there was a direct inverse relationship between numbers of Diporeia and Dreissena in individual samples (Dermott and Kerec 1997). In 1992-1993, D. polymorpha was not abundant at most sites in the southeastern region. However, with a counterclockwise circulation pattern in southern Lake Michigan, extensive D. polymorpha populations in the south-southwestern portion of the lake may have affected Diporeia populations in areas to the east. Changes in water clarity and pelagic productivity have been observed in areas with low $D$. polymorpha populations when circulation patterns integrate waters from nearby areas with higher populations (Fahnenstiel et al. 1995a). Also, since physical processes readily resuspend and transport organic matter from nearshore to offshore areas in the southern basin (Eadie et al. 1984), we suspect that the filtering activities of extensive $D$. polymorpha populations in shallow, nearshore areas are causing decreased benthic inputs to Diporeia in deeper areas.

Many species of fish feed heavily on Diporeia, and changes in Diporeia densities have been related to shifts in fish communities and predation pressure (Johnson and McNeil 1986; McDonald et al. 1990). Thus, the role of fish predation in causing observed changes in Diporeia densities must be examined. Between 1980-1981 and 1992-1993, a number of changes occurred in the nearshore fish communities of Lake Michigan. In the early years of this period, the decline in alewife (Alosa pseudoharengus), which began in 
the 1970s, continued, while yellow perch (Perca flavescens) and bloater (Coregonus hoyi) increased (Jude and Tesar 1985; Fabrizio et al. 1995). McDonald et al. (1990) found a twofold decline in Diporeia densities between 1979-1980 and 1984-1985 in the southern basin and attributed this decline to increased predation from perch and bloater. We did not sample in 1984 or 1985, but benthic samples were taken at one of our sites (H-31) in these same two years (M.A. Quigley, Great Lakes Environmental Research Laboratory, unpublished data). H-31 is located off Grand Haven, Mich., in the same general location where McDonald et al. (1990) sampled. Mean densities of Diporeia at this site in 1980, 1981, 1984, 1985, 1986, and 1987 were 10362,10048 , $7519,7815,9354$, and $10687 \cdot \mathrm{m}^{-2}$, respectively. Densities at this site do indeed appear lower in 1984 and 1985, which agrees with the findings of McDonald et al. (1990). However, note that densities in 1986-1987 were similar to densities in 1980-1981, so any predation effects appear to have been temporary. Also, minimal declines in Diporeia between 1980-1981 and 1986-1987 at <50 m suggest that potential increases in fish predation (at least from perch and bloater) had little impact on overall densities. In the period between 1986-1987 and 1992-1993, yellow perch declined dramatically in the southern basin, while bloater and other fish species that feed heavily on Diporeia declined or remained fairly stable (Fabrizio et al. 1995). Given that the greatest declines in Diporeia occurred over this period (Table 2), it appears that changes in fish predation cannot account for the observed declines.

Unlike Diporeia, declines in oligochaetes and sphaeriids in the south-southeastern portion of the study area were not significantly different from declines in other areas, implying minimal $D$. polymorpha impacts. For oligochaetes, these findings are consistent with those in eastern Lake Erie where oligochaete densities were unaffected by the presence of Dreissena (Dermott and Kerec 1997). Oligochaetes are infaunal detritivores that are not as dependent on freshly settled material as Diporeia (Gardner et al. 1985) and potentially utilize $D$. polymorpha feces and pseudofeces as a food source. In some studies, oligochaete densities actually increased after D. polymorpha became established (Stewart and Haynes 1994). Decreased oligochaete densities between 1980-1981 and 1992-1993 in our study area would therefore indicate a true response to declines in nutrient loads and overall productivity. The relative proportion of the oligotrophic indicator $S$. heringianus did increase at three of the four depth intervals, which is consistent with a shift to more oligotrophic conditions. The reason for the contrary trend at the $31-50 \mathrm{~m}$ interval is not clear. Although total oligochaete densities at this depth interval declined, there was an increase in densities of Tubifex tubifex and immatures of the type with hair setae, most likely immatures of this species. Tubifex tubifex is considered a eutrophic indicator species but also does well in oligotrophic waters (Milbrink 1983). When oligochaete densities increased between the mid1960s and 1980-1981, an overall shift in species composition did not occur (Nalepa 1987).

For sphaeriids, our findings in Lake Michigan contrast with those in Lake Erie where this group declined dramatically in areas where D. polymorpha was abundant (Dermott and Kerec 1997). Of the three major groups, sphaeriids were the least abundant, and declined the most, at all of our depth intervals. With such a marked decline in sphaeriids throughout the study area, regional declines specific to D. polymorpha impacts may have been difficult to discern. Also, the dominant sphaeriid genus in the southern basin is Pisidium (Nalepa et al. 1985). This genus occurs in the upper sediments and feeds by filtering suspended microorganisms from interstitial waters (Lopez and Holopainen 1987). Thus, like oligochaetes, it is not dependent on freshly settled algal material as a direct source of food.

Macroinvertebrate densities declined to the greatest extent at depths $<30 \mathrm{~m}$, were less pronounced at $30-50 \mathrm{~m}$, and were minimal at depths $>50 \mathrm{~m}$. A similar depth-dependent response was apparent when densities increased between the mid-1960s and 1980-1981 (Nalepa 1987). Such a benthic response might be expected, as pelagic productivity is greater and more closely integrated with nutrient inputs in nearshore waters compared with offshore (Ladewski and Stoermer 1973; Schelske et al. 1980). At the shallowest interval, rates of decline in oligochaetes and sphaeriids were greater early in the study period (1980-1981 to 1986-1987) compared with later (1986-1987 to 1992-1993), indicating a rapid early response to load reductions. In reality, declines might have been observed earlier if densities had been documented in the 1970s. At the 31-50 m interval, rates of decline were greater in the later time period, indicating more of a delayed response to productivity declines. At the very least, observed declines in both the 16-30 and 31-50 $\mathrm{m}$ intervals seemed consistent with the turnover time of bottom particulate material in the southern basin, which is estimated to be 9 years at $12 \mathrm{~m}, 16$ years at $65 \mathrm{~m}$, and 23 years at $100 \mathrm{~m}$ (Robbins et al. 1998).

Oligochaetes and sphaeriids were not uniformly distributed throughout the study area at depths $<50 \mathrm{~m}$; higher densities were found near Waukegan and in the depositional basins of the southeastern portion of the lake (Fig. 3). Despite these spatial differences, density declines occurred to a similar extent throughout the study area. This apparent inconsistency is likely a reflection of the high degree of mixing and materials transport that occurs within the nearshore of the southern basin (Chambers and Eadie 1981; Eadie et al. 1984). Within this region, particulate material is constantly being redistributed by storms and longshore currents before being transported to deeper waters. Resuspension occurs on the order of weeks or months, while transport occurs over years. These physical processes greatly influence spatial distributions of macroinvertebrate communities in the nearshore (Stimpson et al. 1975; Winnell and White 1985).

Most permanent deposition of particulate material in Lake Michigan occurs at depths $>50 \mathrm{~m}$ (Edgington and Robbins 1975). Because of the integrative nature of food inputs to this deep region, $60-100 \mathrm{~m}$ has been suggested as the best sampling depth interval to monitor trends in benthic populations relative to the changing trophic status of the lake (Winnell and White 1985). This may be true over the long term, but the response of the macroinvertebrate community to trophic changes occurs more slowly at these depths, and therefore, longer time periods between surveys are needed to detect changes. In the 13-year time interval of this study, declines were apparent for all groups at depths $<50 \mathrm{~m}$, but only sphaeriids declined at depths $>50 \mathrm{~m}$. Similarly, in the ap- 
proximately 15 -year time period between the mid-1960s and 1980-1981, all groups increased at depths $<50 \mathrm{~m}$, but only oligochaetes increased at depths $>50 \mathrm{~m}$ (Nalepa 1987). With the relatively long turnover time of benthic particulate material at deeper depths, our inability to detect consistent changes in all groups was likely a result of the short time span between our surveys. Robertson and Alley (1966) found that Diporeia, oligochaetes, and sphaeriids increased in the deeper waters of Lake Michigan between 1931 and 1964, a time span of 33 years.

In summary, densities of the three dominant macroinvertebrate groups in southern Lake Michigan declined dramatically between the early 1980s and early 1990s at depths $<50 \mathrm{~m}$; by 1993 , densities were equal to or lower than densities found in the mid-1960s. Both reductions in phosphorus loads and the filtering activities of $D$. polymorpha likely played a role in this decline. Oligochaetes and sphaeriids were most impacted by nutrient reductions, while Diporeia was apparently most impacted by $D$. polymorpha. Of utmost concern is the decline in Diporeia populations in the southeast region of the lake where numbers at many sites $<50 \mathrm{~m}$ were approaching zero in 1993. As D. polymorpha spreads and becomes increasingly abundant, further declines in Diporeia populations may be expected. Further declines are also imminent if the other Dreissena species, Dreissena bugensis, becomes established on the soft, offshore sediments of Lake Michigan as it has in lakes Erie and Ontario (Mills et al. 1993; Dermott and Kerec 1997). Because Diporeia accounts for a major portion of benthic invertebrate biomass in Lake Michigan (Nalepa 1989) and is a major energy link between pelagic production and fish (Gardner et al. 1990), declines in Diporeia over large areas will likely lead to serious disruptions in the Lake Michigan food web.

\section{Acknowledgements}

We thank the following people whose contributions are much appreciated: B. Burns for his support during field operations, J. Buchanan, R. Derosario, G. Gostenik, J. Holman, P. Hurst, K. McElroy, M. Lansing, and A. Vielmetti for their dedication in picking and sorting, S. Brandt and P. Landrum for helpful comments, and A. Beeton, M. Quigley, T. Johengen, and J. Robbins for access to unpublished data. This is GLERL contribution No. 1079.

\section{References}

Alley, W.P., and Mozley, S.C. 1975. Seasonal abundance and spatial distribution of Lake Michigan macrobenthos, 1964-67. Great Lakes Research Division Spec. Publ. 54, University of Michigan, Ann Arbor, Mich.

Botts, P.S., Patterson, B.A., and Schloesser, D.W. 1996. Zebra mussel effects on benthic invertebrates: physical or biotic? J. N. Am. Benthol. Soc. 15: 179-184.

Chambers, R.L., and Eadie, B.J. 1981. Nepheloid and suspended particulate matter in south-eastern Lake Michigan. Sedimentology, 28: 439-447.

Chang, W.Y.B., and Rossman, R. 1988. Change in the abundance of blue green algae related to nutrient loadings in the nearshore of Lake Michigan. Hydrobiologia, 157: 271-278.

Chapra, S. 1977. Total phosphorus model for the Great Lakes. 1977. J. Environ. Eng. Div. 103: 147-161.
Clarke, K.D., Knoechel, R., and Ryan, P.M. 1997. Influence of trophic role and life-cycle duration on timing and magnitude of benthic macoinvertebrate response to whole-lake enrichment. Can. J. Fish. Aquat. Sci. 54: 89-95.

Cook, D.G., and Johnson, M.G. 1974. Benthic macroinvertebrates of the St. Lawrence Great Lakes. J. Fish. Res. Board Can. 31: 763-782.

Dermott, R., and Kerec, D. 1997. Changes in the deepwater benthos of eastern Lake Erie since the invasion of Dreissena: 1979-1993. Can. J. Fish. Aquat. Sci. 54: 922-930.

Eadie, B.J., Chambers, R.L., Gardner, W.S., and Bell, G.L. 1984. Sediment trap studies in Lake Michigan: resuspension and chemical fluxes in the southern basin. J. Great Lakes Res. 10: 307-321.

Edgington, D.N., and Robbins, J.A. 1975. The behavior of plutonium and other long-lived radionuclides in Lake Michigan. II. Patterns of deposition in the sediments. In Impact of nuclear releases into the aquatic environment. IAEA, Vienna, Austria. pp. 245-260.

Edsall, T.A., and Charlton, M.N. 1996. Nearshore waters of the Great Lakes. Background Paper, State of the Lakes Ecosystem Conference '96, Environment Canada-U.S. EPA, EPA 905-D96-001b.

Fabrizio, M.C., Ferreri, C.P., and Hansen, M.J. 1995. Prey fish communities as indicators of ecosystem health in Lake Michigan. Project Completion Report to the Environmental Protection Agency. Great Lakes Science Center, U.S. Geological Survey, Ann Arbor, Mich.

Fahnenstiel, G.L., Lang, G.A., Nalepa, T.F., and Johengen, T.H. 1995a. Effects of zebra mussel (Dreissena polymorpha) colonization on water quality parameters in Saginaw Bay, Lake Huron. J. Great Lakes Res. 21: 435-448.

Fahnenstiel, G.L., Bridgeman, T.B., Lang, G.A., McCormick, M.J., and Nalepa, T.F. 1995b. Phytoplankton productivity in Saginaw Bay, Lake Huron: effects of zebra mussel (Dreissena polymorpha) colonization. J. Great Lakes Res. 21: 465-475.

Gardner, W.S., Nalepa, T.F., Frez, W.A., Cichocki, E.A., and Landrum, P.F. 1985. Seasonal patterns in lipid content of Lake Michigan macroinvertebrates. Can. J. Fish. Aquat. Sci. 42: 1827-1832.

Gardner, W.S., Quigley, M.A., Fahnenstiel, G.L., Scavia, D., and Frez, W.A. 1990. Pontoporeia hoyi - a direct trophic link between spring diatoms and fish in Lake Michigan. In Large lakes: ecological structures and functions. Edited by M.M. Tilzer and C. Serruya. Springer-Verlag, Berlin, Germany.

Johengen, T.H., Johannsson, O.E., Pernie, G.L., and Millard, E.S. 1994. Temporal and seasonal trends in nutrient dynamics and biomass measures in Lakes Michigan and Ontario in response to phosphorus control. Can. J. Fish. Aquat. Sci. 51: 2570-2578.

Johnson, M.G., and McNeil, O.C. 1986. Changes in abundance and species composition in benthic macroinvertebrate communities of the Bay of Quinte, 1966-1984. In Project Quinte: pointsource phosphorus control and ecosystem response in the Bay of Quinte, Lake Ontario. Edited by C.K. Minns, D.A. Hurley, and K.H. Nicholls. Can. Spec. Publ. Fish. Aquat. Sci. No. 86.

Jude, D.J., and Tesar, F.J. 1985. Recent changes in the inshore forage fish of Lake Michigan. Can. J. Fish. Aquat. Sci. 42: 11541157.

Ladewski, T.B., and Stoermer, E.F. 1973. Water transparency of southern Lake Michigan in 1971 and 1972. Proceedings of the 16th Conference on Great Lakes Research. International Association for Great Lakes Research, Ann Arbor, Mich. pp. 791-807.

Lang, C., and Reymond, O. 1992. Reversal of eutrophication in 
Lake Geneva: evidence from the oligochaete communities. Freshwater Biol. 28: 145-148.

Lauritsen, D.D., Mozley, S.C., and White, D.S. 1985. Distribution of oligochaetes in Lake Michigan and comments on their use as indices of pollution. J. Great Lakes Res. 11: 67-76.

Lopez, G.R., and Holopainen, I.J. 1987. Interstitial suspensionfeeding by Pisidium spp. (Pisidiidae:Bivalvia): a new guild in the lentic benthos? Am. Malacol. Bull. 5: 21-30.

Marsden, J.E., Trudeau, N., and Keniry, T. 1993. Zebra mussel study of Lake Michigan. Aquat. Ecol. Tech. Rep. 93/14, Illinois Natural History Survey, Zion, Ill.

McDonald, M.E., Crowder, L.B., and Brandt, S.B. 1990. Changes in Mysis and Pontoporeia populations in southeastern Lake Michigan: a response to shifts in the fish community. Limnol. Oceanogr. 35: 220-227.

Milbrink, G. 1983. An improved environmental index based on the relative abundance of oligochaete species. Hydrobiologia, 102: 89-97.

Mills, E.L., Dermott, R.M., Roseman, E.F., Dustin, D., Mellina, E., Conn, D.B., and Spidel, A. 1993. Colonization, ecology, and population structure of the "quagga mussel" in the lower Great Lakes. Can. J. Fish. Aquat. Sci. 50: 2305-2314.

Nalepa, T.F. 1987. Long term changes in the macrobenthos of southern Lake Michigan. Can. J. Fish. Aquat. Sci. 44: 515-524.

Nalepa, T.F. 1989. Estimates of macroinvertebrate biomass in Lake Michigan. J. Great Lakes Res. 15: 437-443.

Nalepa, T.F., Quigley, M.A., Childs, K.F., Gauvin, J.M., Heatlie, T.S., Parker, M.P., and Vanover, L. 1985. Macrobenthos of southern Lake Michigan, 1980-81. NOAA Data Rep. ERL GLERL-28. Great Lakes Environmental Research Laboratory, Ann Arbor, Mich.

Nalepa, T.F., Hartson, D.J., Gostenik, G.W., Fanslow, D.L., and Lang, G.A. 1996. Changes in the freshwater mussel community of Lake St. Clair: from Unionidae to Dreissena polymorpha in eight years. J. Great Lakes. Res. 22: 354-369.

Robbins, J.A., Eadie, B.J., and Edgington, D.N. 1998. Spatially variable, first order averaging of cesium-137 fluxes to sediments in Lake Michigan revealed by long-term changes in activities of benthic trap samples and sediments. Ocean Sciences Meeting. American Geophysical Union, San Diego, Calif. (Abstr.)
Robertson, D.M. 1997. Regionalized loads of sediment and phosphorus to Lakes Michigan and Superior - high flow and longterm average. J. Great Lakes Res. 23: 416-439.

Robertson, A., and Alley, W.P. 1966. A comparative study of Lake Michigan macrobenthos. Limnol. Oceanogr. 11: 576-583.

Saether, O.A. 1980. The influence of eutrophication on deep lake benthic invertebrate communities. Prog. Water Technol. 12: 161-180.

Scavia, D., Fahnenstiel, G.L., Evans, M.S., Jude, D.J., and Lehman, J.T. 1986. Influence of salmonid predation and weather on long-term water quality trends in Lake Michigan. Can. J. Fish. Aquat. Sci. 43: 435-443.

Schelske, C.L. 1978. Detecting trends in Great Lakes water quality. In The Great Lakes. 2. Water Qual. Bull. Vol. 3. Canada Centre for Inland Waters, Burlington, Ont.

Schelske, C.L., Feldt, L.E., and Simmons, M.S. 1980. Phytoplankton and physical-chemical conditions in selected rivers and the coastal zone of Lake Michigan, 1972. Great Lakes Research Division Publ. 19, University of Michigan, Ann Arbor, Mich.

Schloesser, D.W., Reynoldson, T.B., and Manny, B.A. 1995. Oligochaete fauna of western Lake Erie 1961 and 1982: signs of sediment quality recovery. J. Great Lakes Res. 21: 294-306.

Stewart, T.W., and Haynes, J.M. 1994. Benthic macroinvertebrate communities of southwestern Lake Ontario following invasion of Dreissena polymorpha. J. Great Lakes Res. 20: 479-493.

Stimpson, K.S., Brice, J.R., Barbour, M.T., and Howe, P. 1975. Distribution and abundance of inshore oligochaetes in Lake Michigan. Trans. Am. Microsc. Soc. 94: 384-394.

Vandercastle, J.R. 1985. A study of long-term changes of the phytoplankton community and seasonal changes in alkaline phosphate activity observed in Lake Michigan. Ph.D. thesis, University of Wisconsin, Milwaukee, Wis.

Wiederholm, T. 1980. Use of benthos in lake monitoring. J. Water Pollut. Control Fed. 52: 537-547.

Winnell, M.H., and White, D.S. 1984. Ecology of shallow and deep water populations of Pontoporeia hoyi (Smith) (Amphipoda) in Lake Michigan. Freshwat. Invertebr. Biol. 3: 118-138.

Winnell, M.H., and White, D.S. 1985. Trophic status of southeastern Lake Michigan based on the Chironomidae (Diptera). J. Great Lakes Res. 11: 540-548. 